DOI: $10.17951 / 1 r p .2018 .37 .2 .171-178$

\author{
Vitalii Zaika \\ Poltava Open International University of Human Development "Ukraine" \\ ORCID: https://orcid.org/0000-0001-5710-2997
}

\title{
PROTECTION OF RIGHTS OF PEOPLE WITH SPECIAL EDUCATIONAL NEEDS IN UKRAINE
}

\begin{abstract}
In the article, the author analyzes three models of attitudes towards people with special needs in the world: the medical model, the model of normalization, and social model, as well as defines priority humanistic approach based on respect for human dignity, rights and freedoms of every individual, regardless of gender, age or state of health. The basic needs of people with disabilities are identified, as well as the need for self-realization by which people seek to find their place in life and to realize their potential, talents, professional self-determination. We considered internal and external support mechanisms of "the disabled" in their development, for whom inclusive education aims at: creating favorable psychological climate in the family; creating cultural system in society; support from the government in professional and creative self-realization; social prevention and control of negative attitudes towards people with disabilities; providing equal rights by state, that erasure boundaries between "healthy" people and those with disabilities; positive self-perception and self-attitude; active life; a clear identity and personalization; responsibility, freedom and a strong will; belief in yourself and a positive assessment of one's own and other people's capabilities. We considered foreign and domestic regulations that ensure the rights of people with special needs: the Universal Declaration of Human Rights (1948), the Declaration of the Rights of the Child (1959), the Declaration on the Rights of Mentally Retarded Persons (1971), the Declaration on the Rights of Disabled Persons (1975), the Vocational Rehabilitation and Employment (Disabled Persons) Convention (1983), Convention on the Rights of the Child (1989), Standard Rules on the Equalization of Opportunities for Persons with Disabilities (1993), the Salamanca Statement on Principles, Policy and Practice in Special Needs Education and a Framework for Action (1994), the Dakar Declaration (2000), the Convention on the Rights of Persons with Disabilities (2006, New York) and others.
\end{abstract}

Keywords: people with special educational needs, basic needs, self-realization, self-support mechanisms in self-realization, inclusive education, regulations

Every year in Ukraine, the number of disabled persons is increasing. This is mainly due to the low level of medical care, the growth of drug addiction and 
alcoholism, increased environmental hazards, traffic accidents, industrial and domestic accidents, armed conflict in eastern Ukraine, early childhood disability and so on. Staying relevant to today, the issue becomes more acute and important at the beginning of the third millennium, in a social transformation that significantly affects the fate of the individual and determines its way of life.

In the media and in literature, different concepts are used in parallel: the disabled, the handicapped, people with disabilities, people with special needs, persons with disabilities. This ambiguous definition and interpretation of the term "disability" describes various aspects and approaches to problem-solving training, education, treatment, rehabilitation and social protection of the disabled not only in Ukraine but also worldwide.

In legal documents of Ukraine, the terms "disabled person" and "disability" are predominant. Disabled person - a person who has health problems with persistent disorder of body functions, caused by the disease, trauma or defects that results in reduced life and necessitate social protection. Disability - a restriction of capabilities caused by physical, mental, sensory, social, cultural, legal and other barriers that do not allow people to be integrated into society and participate in family and state life on the conditions that apply for other members of society.

Humanization of societies around the world requires an appropriate attitude to people with special needs, such as their social adaptation to everyday life and getting a proper education and employment. The legal instruments have enabled people with disabilities to get all levels of education from primary to higher without discrimination of their rights.

Theoretical and methodological problems of inclusive education were examined by both domestic (A.A. Aghababyan, M. Bilera, L.I. Danilenko, T.D. Illyashenko, I.A. Kalinichenko, V. Kyrylenko, O.V. Kobzar, A.A. Kolupaev, K.O. Kolchenko, V.A. Kulyesh, S.V. Lytovchenko, Y.M. Naida, G.F. Nikulina, A.G. Obukhov, P.M. Pridatchenko, N.Z. Sofiy, P.M. Talanchuk, G.M. Umanets, O.M. Fudorova, M.E. Tchaikovsky, V.V. Chizhik) and foreign (F. Amstronh, B. Barber, H. Becker, N. Borisov, F. Crosby) scientists.

The aim of this publication is to study the problem of protecting the rights of people with special needs in Ukraine as an important part of integration into the European educational continuum. 


\section{ATTITUDE MODELS TOWARDS PEOPLE WITH SPECIAL NEEDS IN THE WORLD}

World experience in solving problems of people with disabilities has come a long, bumpy way as far as their exclusion from and inclusion on the society is concerned. During this time, in the world, there were three models of attitudes towards the disabled: the medical model, the model of normalization and social model (Danylenko 2007).

Medical model (segregation) - early $20^{\text {th }}$ century-mid-1960s. This pattern suggests that the person with developmental problems is a sick person who needs long-term care and treatment that can be provided in special schools.

Model of normalization (integration) - mid-1960s-mid-1980s. This model, during the 1960s, has defined policy in relation to children with special needs. During this period, the integration of children with special needs in the environment of conventional peers became the norm. Integration in this context is seen as assimilation process that requires from a person to accept rules specific to the dominant culture. A person must be "ready" for being accepted by society. The basis of the concept of "normalization" are the following provisions: a child with special needs is someone who develops / is able to develop different activities; society must recognize this and provide living conditions mostly close to universally accepted standards.

The social model (involvement, inclusion) - mid-1980s-present. The basis of the social model is the statement: a man does not have to be "ready" to participate in society, to learn at school, to work. Social model aims to change society in such a way that it ensures equal participation of its citizens in the exercise of their rights and gives them this opportunity.

Thus, M. Bilera notes that

(...) the processes of humanization of social life require further solving the noble task - to find ways to improve the "value of life", to increase the efficiency of the means of social integration, adaptation, rehabilitation of disabled people, to ensure their active participation in life along with healthy people (Bilera 2013, p. 50).

\section{SELF-REALIZATION OF PEOPLE WITH SPECIAL NEEDS}

The main problem that needs immediate solution is: overcoming the social isolation of persons with disabilities and limited possibilities of communication; organization of leisure time and learning; finding potential earnings. People with disabilities need not only material support and measures of medical, vocational and social 
and home rehabilitation, but also creation of appropriate conditions for improving their skills, personal character development and realizing their needs in social, moral and spiritual self-improvement.

One of the major methods of social work with people with disabilities is a method of stimulating progressive public opinion regarding the formation of positive social and humane treatment of these people, their families, creating an atmosphere of goodwill and understanding of their problems.

Psychological science is dominated by the belief that a person is a true person only if his basic needs are satisfied. Pyramid of general human needs was developed and implemented in psychological science by A. Maslow in the last century (Hjelle, Ziegler 1992). The first step in the pyramid is meeting the physiological needs of a man as a biological organism required for basic survival (breathing, food, water, sleep). Another, more advanced, step of pyramid of needs is the need for security, which includes the need to protect from physical and psychological dangers of the outside world and the belief that physiological needs will be met in the future. Social needs (need for belonging, friendship, love) include a sense of belonging to anything's or anyone's support. Slightly higher in the pyramid of needs are needs for dignity and respect, which include the need for personal achievement, competence, respect from others, recognition. The highest element in Maslow's hierarchy of needs is the need for self-expression, self-realization - the need for the realization of their potential and growth as a person. With the loss of the aforementioned steps, this desire in man disappears.

Although the least important needs of people with disabilities are somehow satisfied, it is not always the case with self-realization or self-actualization. It goes back to the time when the child begins to learn the world, studies letters, learns to write, takes his example from parents and others. Everyone wants to realize oneself in life, and incrementally achieve his/her goal. This is especially true for children with special needs who, for some reason, are not always provided with equal opportunities as compared to a healthy person. This is due to various reasons: improper training and lack of special treatment of such a child, including domestic violence, peer stress, feeling of failure and frustration, complexes, stigmatization, etc.

Adults with disabilities also have their difficulties in self-realization. The disabled, like other (healthy) people, tend to find their place in life, realize their potential, talents, professional self-determination. However, for the "disabled" it is much more difficult, so one should consider internal and external support mechanisms of "disabled" in their development.

External support mechanisms include:

1) favorable psychological climate in the family;

2) creating a cultural system in society; 
3) support from the state in a professional and creative self-realization;

4) social prevention and control of negative attitudes towards people with disabilities;

5) equal rights and opportunities provided by the state that erase the boundaries between the "healthy" and people with disabilities and others.

Internal support mechanisms include:

1) positive self-image and self-attitude;

2) active life position;

3) clear identity and personalization;

4) responsibility, freedom and a strong will;

5) self-confidence and positive assessment of one's and other people's capabilities.

Inclusive education is specifically aimed at teaching students or students with disabilities by including them in the overall educational environment.

Many international law documents protect rights of such people. Among them the following can be mentioned: the Universal Declaration of Human Rights (1948), the Declaration of the Rights of the Child (1959), the Declaration on the Rights of Mentally Retarded Persons (1971), the Declaration on the Rights of Disabled Persons (1975), the Vocational Rehabilitation and Employment (Disabled Persons) Convention (1983), Convention on the Rights of the Child (1989), Standard Rules on the Equalization of Opportunities for Persons with Disabilities (1993), the Salamanca Statement on Principles, Policy and Practice in Special Needs Education and a Framework for Action (1994), the Dakar Declaration (2000) and the Convention on the Rights of Persons with Disabilities (2006, New York) which became the starting document for legislative consolidation of inclusive policies and practices at the national level.

\section{IMPLEMENTATION OF THE RIGHTS OF PEOPLE WITH SPECIAL NEEDS IN UKRAINE}

In Ukraine, the status of people with disabilities is also legally protected. The provisions concerning this issue are provided for by the Laws of Ukraine: "On Education" (1991), "On the Basis of Social Protection of the Disabled in Ukraine" (1991), "On State Social Standards and Social Guarantees" (2000), "On Protection of Childhood" (2001), "On Social Services" (2003), "On the Rehabilitation of the Disabled in Ukraine" (2005). The above-mentioned documents contain provisions regarding inclusive educational, health, and social services to people with disabilities, in particular children with special educational needs (Aghababyan 2013). 
In Ukraine, the Convention on the Rights of People with Disabilities was ratified by the Verkhovna Rada of Ukraine on 16 December 2009. The Convention on the Rights of Persons with Disabilities and its Optional Protocol (adopted on 13 December 2006 in New York) became one of the most prominent international instruments to protect the rights of people with disabilities, which recognized the proclaimed (by the United Nations) Universal Declaration of Human Rights and the International Covenants on Human Rights, and Rights of Persons with Disabilities and elaborated them, including the rights of children with disabilities. The preamble of the document states that "disability is an evolving concept and that disability results from the interaction between people with imparments and attitudinal and environmental barriers that hinders and their full and effective participation in society on an equal basis with others" and that "persons with disabilities continue to stumble upon barriers to their participation in society as full members and violation of their human rights in all parts of the world".

Of particular note is Article 24 (Education), which states that "States Parties recognize the right of persons with disabilities to education. For the purposes of this right without discrimination and on the basis of equal opportunity, States Parties shall ensure an inclusive education at all levels throughout life" and that

(...) States Parties shall ensure that persons with disabilities are not excluded from the general education system and children with disabilities - from the system of free and compulsory primary or secondary education; provision of reasonable accommodation of the individual's needs; getting inside the general education system a necessary support to facilitate effective education; access to secondary education, vocational training, adult education and lifelong learning without discrimination and on an equal basis with others.

In 2001, the Ministry of Education and Science of Ukraine began a Ukrainian research and teaching experiment "Social rehabilitation and integration of children with special needs by organizing their education in secondary schools", and from 2008, it started a new research and teaching experiment "Social adaptation and integration of children requiring correction of physical and (or) mental development through the introduction of inclusive education", which lasted until the end of 2013.

There is also the order of the Ministry of Education and Science of Ukraine No. 912 of 1 October 2010 “The Concept of Inclusive Education” which must fulfill the following objectives:

1) improving the legal, scientific, methodical, financial and economic support oriented towards the implementation of inclusive education; 
2) the introduction of innovative technologies in the context of an inclusive approach, of forms and models for special education services for children with special educational needs, including those with disabilities;

3) formation of educational and developmental environment for children with special educational needs by providing psychological, educational, medical and social support;

4) implementation of inclusive teaching in secondary schools according to the needs of society;

5) providing access to social protection and training facilities, to development and use of special educational and didactic support, rehabilitation training facilities;

6) improving training and retraining of teachers, working in conditions of inclusive education;

7) engaging parents of children with special needs to participate in educational and rehabilitation process in order to increase its effectiveness.

After the revolution of 2014 and in the conditions of the integration into the European educational space with European values based on respect for human dignity, rights and freedoms of every person, inclusive education in Ukraine has become widespread. So, the Decree of the Ministry of Education and Science No. 1436 of 31 December 2015 "On Approval of the Action Plan to Ensure the Right for Education of Children with Special Educational Needs in General Education Space", came into force. The Ministry of Education and Science of Ukraine has created a Department of Education of Children with Special Needs, which aims to implement the law of Ukraine as well as Decrees of the President of Ukraine to ensure equal access to quality education for children with special educational needs, the introduction of inclusive education, improvement of methodological support of education of children with special needs, orphans and children deprived of parental care.

To sum up, in Ukraine, social and psychological protection of the rights of people with special educational needs are implemented properly. Currently, according to the Ministry of Education and Science, the following institutions operate in Ukraine: 334 special secondary schools, including those for orphans and children deprived of parental care, with a total of 38,962 students. As regards inclusive classes in secondary schools, there are 2,720 students with special educational needs, and in special classes - 5,265 students. Many people with special needs get higher education, particularly, in different departments of the University "Ukraine". 


\title{
REFERENCES
}

Агабабян, А.О., 2013, Освіта людей з особливими потребами: нормативно-правовий аспект. «Державне будівництво», № 1.

Білера, М., 2013, Проблеми освіти та реабілітацї осіб з інвалідністю у вищих навчальних закладах. Молодіжний науковий вісник: «Фізичне виховання і спорт», № 9.

Концептуальні аспекти інклюзивної освіти, 2007. In: Л.І. Даниленко (ред.), Інклюзивна школа: особливості організацї та управління. Київ: Всеукраїнський фонд «Крок за кроком».

Hjelle, L.A., Ziegler, D.J., 1992, Personality Theories: Basic Assumptions, Research and Applications. New York: McGraw-Hill College.

\section{OCHRONA PRAW OSÓB ZE SPECJALNYMI POTRZEBAMI}

\begin{abstract}
Abstrakt: W artykule autor przeanalizował trzy modele postaw wobec osób o specjalnych potrzebach na świecie (model medyczny, model normalizacji i model społeczny) oraz określił priorytetowe podejście humanistyczne oparte na poszanowaniu godności ludzkiej, praw i wolności każdej osoby, niezależnie od płci, wieku czy stanu zdrowia. Wskazano też podstawowe potrzeby osób niepełnosprawnych oraz potrzebę samorealizacji, w wyniku której ludzie starają się odnaleźć swoje miejsce w życiu i wykorzystać swój potencjał, talenty, profesjonalną determinację. Uwzględnione zostały wewnętrzne i zewnętrzne mechanizmy wsparcia „niepełnosprawnych” w ich rozwoju, dla których edukacja włączająca ma na celu: zbudowanie korzystnego klimatu psychologicznego w rodzinie; stworzenie systemu kulturowego w społeczeństwie; uzyskanie wsparcia rządu w profesjonalnej i twórczej samorealizacji; zapobieganie społecznym negatywnym postawom wobec osób niepełnosprawnych i ich kontrolę; zapewnienie równych praw przez państwo; usuwanie granic między „zdrowymi” a osobami niepełnosprawnymi; pozytywne postrzeganie siebie; aktywne życie; wyraźną tożsamość i personalizację; odpowiedzialność, wolność i silną wolę; wiarę w siebie i pozytywną ocenę możliwości (swoich i innych osób). W opracowaniu przedstawiono zagraniczne i krajowe przepisy gwarantujące prawa osób o szczególnych potrzebach, takie jak: Powszechna deklaracja praw człowieka (1948), Deklaracja praw dziecka (1959), Deklaracja praw osób upośledzonych umysłowo (1971), Deklaracja praw osób niepełnosprawnych (1975), Konwencja dotycząca rehabilitacji zawodowej i zatrudnienia osób niepełnosprawnych (1983), Konwencja o prawach dziecka (1989), Standardowe zasady wyrównywania szans osób niepełnosprawnych (1993), Deklaracja Salamanki w sprawie zasad, polityki i praktyki w zakresie specjalnych potrzeb edukacyjnych i ramy działania (1994), Deklaracja z Dakaru (2000), Konwencja o prawach osób niepełnosprawnych (2006, Nowy Jork) i inne.
\end{abstract}

Słowa kluczowe: osoby o specjalnych potrzebach edukacyjnych, podstawowe potrzeby, samorealizacja, mechanizmy samoobsługowe w samorealizacji, edukacja włączająca, przepisy 